\title{
BMJ Open Are symptoms of insomnia related to respiratory symptoms? Cross-sectional results from 10 European countries and Australia
}

\author{
Erla Bjornsdottir (D) ,,2 Eva Lindberg, ${ }^{3}$ Bryndis Benediktsdottir, ${ }^{2,4}$ \\ Thorarinn Gislason, ${ }^{2}$ Vanessa Garcia Larsen, ${ }^{5}$ Karl Franklin, ${ }^{6}$ Debbie Jarvis, ${ }^{7}$ \\ Pascal Demoly, ${ }^{8}$ Jennifer L Perret, ${ }^{9}$ Judith Garcia Aymerich, ${ }^{10}$ \\ Sandra Dorado Arenas, ${ }^{11}$ Joachim Heinrich, ${ }^{12}$ Kjell Torén, ${ }^{13}$ Rain Jögi, ${ }^{14}$ \\ Christer Janson (i) ${ }^{15}$
}

To cite: Bjornsdottir E, Lindberg E, Benediktsdottir B, et al. Are symptoms of insomnia related to respiratory symptoms? Cross-sectional results from 10 European countries and Australia. BMJ Open 2020;10:e032511. doi:10.1136/ bmjopen-2019-032511

- Prepublication history and additional material for this paper are available online. To view these files, please visit the journal online (http://dx.doi. org/10.1136/bmjopen-2019032511).

Received 18 July 2019 Revised 21 March 2020 Accepted 31 March 2020
Check for updates

(C) Author(s) (or their employer(s)) 2020. Re-use permitted under CC BY-NC. No commercial re-use. See rights and permissions. Published by BMJ.

For numbered affiliations see end of article.

Correspondence to Dr Erla Bjornsdottir; erlabjo@gmail.com

\section{ABSTRACT}

Objectives To compare the prevalence of different insomnia subtypes among middle-aged adults from Europe and Australia and to explore the cross-sectional relationship between insomnia subtypes, respiratory symptoms and lung function.

Design Cross-sectional population-based, multicentre cohort study.

Setting 23 centres in 10 European countries and Australia.

Methods We included 5800 participants in the third follow-up of the European Community Respiratory Health Survey III (ECRHS III) who answered three questions on insomnia symptoms: difficulties falling asleep (initial insomnia), waking up often during the night (middle insomnia) and waking up early in the morning and not being able to fall back asleep (late insomnia). They also answered questions on smoking, general health and chronic diseases and had the following lung function measurements: forced expiratory volume in $1 \mathrm{~s}\left(\mathrm{FEV}_{1}\right)$, forced vital capacity (FVC) and the $\mathrm{FEV}_{1} / \mathrm{FVC}$ ratio. Changes in lung function since ECRHS I about 20 years earlier were also analysed.

Main outcome measures Prevalence of insomnia subtypes and relationship to respiratory symptoms and function.

Results Overall, middle insomnia (31.2\%) was the most common subtype followed by late insomnia $(14.2 \%)$ and initial insomnia (11.2\%). The highest reported prevalence of middle insomnia was found in Iceland (37.2\%) and the lowest in Australia (22.7\%), while the prevalence of initial and late insomnia was highest in Spain $(16.0 \%$ and $19.7 \%$, respectively) and lowest in Denmark (4.6\% and $9.2 \%$, respectively). All subtypes of insomnia were associated with significantly higher reported prevalence of respiratory symptoms. Only isolated initial insomnia was associated with lower $\mathrm{FEV}_{1}$, whereas no association was found between insomnia and low $\mathrm{FEV}_{1} / \mathrm{FVC}$ ratio or decline in lung function.

Conclusion There is considerable geographical variation in the prevalence of insomnia symptoms. Middle insomnia is most common especially in Iceland. Initial and late
Strengths and limitations of this study

- The strengths of this study include the populationbased nature of this large sample collected in the same manner at many centres in 11 different countries.

- Another strength is the use of standardised and validated procedures and instruments.

- One limitation of our study is the cross-sectional study design that cannot tell us the direction of the association found since the underlying causal pathways can only be obtained from longitudinal or intervention studies.

- Another limitation is the fact that we only have information on insomnia symptoms but not the diagnosis of insomnia disorder.

insomnia are most common in Spain. All insomnia subtypes are associated with respiratory symptoms, and initial insomnia is also associated with lower $\mathrm{FEV}_{1}$.

\section{INTRODUCTION}

A good night's sleep is vital for daily functioning, general health and well-being. ${ }^{1}$ Sleep disturbances are highly prevalent in the general population and often have considerable impact on health and quality of life..$^{2-4}$ Insomnia is categorised as difficulty falling asleep (initial insomnia), waking up often during the night (middle insomnia) and waking up too early in the morning (late insomnia).

Insomnia is common and is associated with various negative consequences for health and well-being. ${ }^{5}$ Previous studies have shown geographical variation in prevalence of sleep disturbances. Léger et at reported sleep disturbances, including insomnia occurring in $6.6 \%-37 \%$ in four countries (France, 


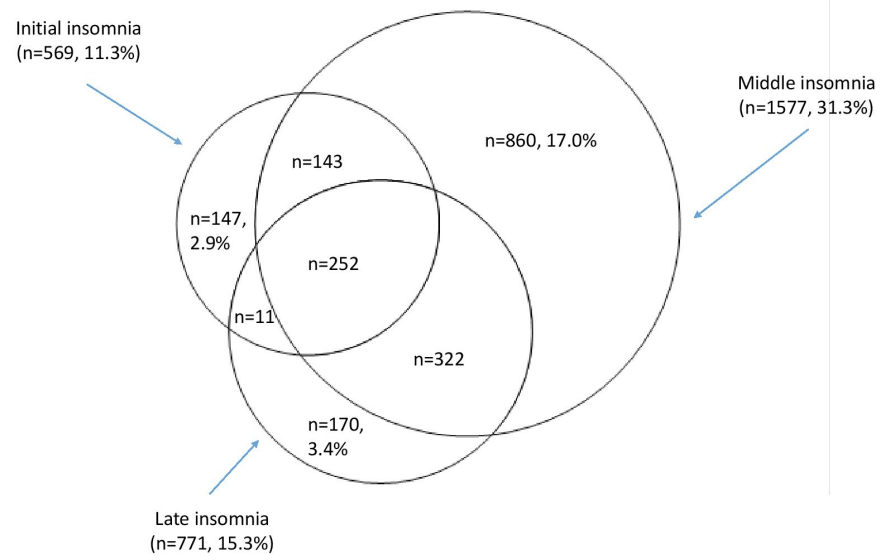

Figure 1 The number of subjects with different insomnia subtypes and the number with isolated insomnia subtypes in the random sample $(n=5043)$.

Italy, Japan and USA). Previous studies conducted in Sweden, Iceland Belgium, Great Britain, Germany and Ireland found the prevalence rates of insomnia to range from $4 \%$ to $22 \% .^{78}$ Furthermore, a study by Dregan and Armstrong ${ }^{9}$ comparing sleep disturbances and their relationship to age among subjects from 23 European countries found substantial differences in sleep patterns across these countries. A similar result was obtained in a recent study of older European adults. ${ }^{10}$ However, these studies used a single item measure of sleep disturbances and could therefore not evaluate different subtypes of insomnia.

Several studies have shown associations between insomnia and respiratory symptoms. ${ }^{11-14}$ Having asthma has been associated with a higher prevalence of insomnia, ${ }^{1516}$ and patients with chronic obstructive pulmonary disease (COPD) commonly report disturbed sleep, including symptoms of insomnia. ${ }^{17}$ There is, however, a lack of large epidemiological studies exploring the association between different insomnia subtypes and respiratory symptoms and between insomnia and lung function using standardised methodology in a large number of countries.

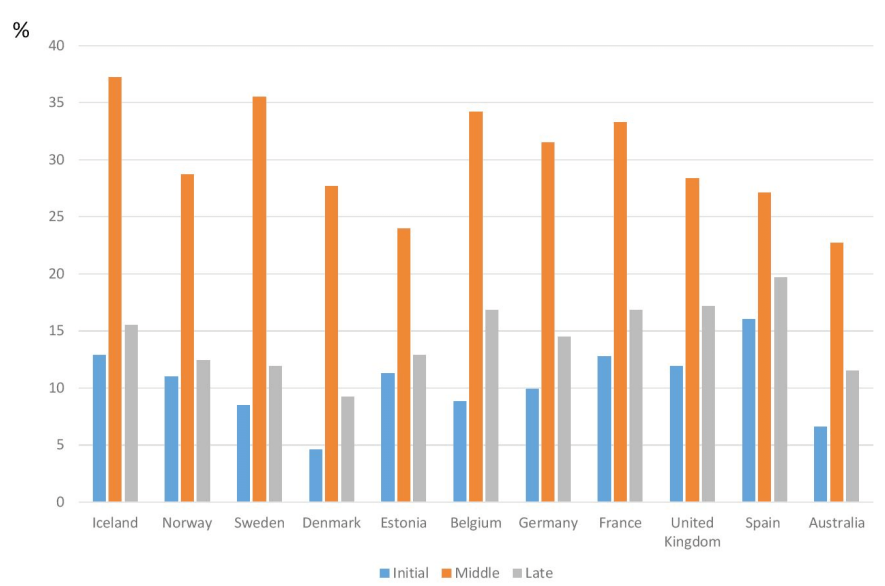

Figure 2 The prevalence of the different insomnia subtypes in the different countries.
Table 1 Characteristics of the participants in ECRHS III with data on sleep disturbances (mean \pm SD and \%)

\begin{tabular}{llll}
\hline & $\begin{array}{l}\text { No insomnia } \\
\text { symptoms } \\
\text { (n=3516) }\end{array}$ & $\begin{array}{l}\text { Insomnia } \\
\text { symptoms } \\
\text { (n=2284) }\end{array}$ & P value \\
\hline Age & $53.7 \pm 7.2$ & $55.2 \pm 6.9$ & $<0.0001$ \\
\hline Women & 48.0 & 59.6 & $<0.0001$ \\
\hline BMl & $27.0 \pm 4.7$ & $27.5 \pm 5.2$ & 0.0002 \\
\hline BMl groups & & & 0.003 \\
\hline$<20$ & 3.3 & 3.0 & \\
\hline 20-25 & 33.9 & 31.7 & \\
\hline$>25-30$ & 40.7 & 38.7 & 0.04 \\
\hline$>30$ & 22.1 & 26.6 & \\
\hline $\begin{array}{l}\text { Smoking } \\
\text { history }\end{array}$ & & & \\
\hline Never & 45.2 & 42.2 & \\
\hline Ex & 36.3 & 39.4 & \\
\hline Current & 18.5 & 18.4 & $12.7 \pm 21.3$ \\
\hline Pack years & $10.8 \pm 17.7$ & & \\
\hline
\end{tabular}

Insomnia symptom refers to individuals who have symptoms of either initial, middle or late insomnia $\geq 3 \times /$ week.

BMI, body mass index; ECRHS III, European Community

Respiratory Health Survey III.

The aim of the present study was to compare the prevalence of different insomnia subtypes among middleaged subjects from 23 centres in 11 countries as well as exploring the relationship of different subtypes of insomnia with respiratory symptoms and lung function.

\section{MATERIAL AND METHODS \\ Subjects}

We studied participants in the third follow-up of the European Community Respiratory Health Survey III (ECRHS III; www.ecrsh.org), an international, population-based, multicentre cohort study of asthma and allergy, which was first performed in 1990. Detailed descriptions of the methods for ECRHS I and ECRHS II have been published elsewhere. ${ }^{18}$ Briefly, participating centres first randomly selected samples of 20-44year old subjects. Participants completed a short postal questionnaire about asthma and asthma-like symptoms, and from those who responded, a random sample was selected to undergo a more detailed clinical examination. In addition, a 'symptomatic sample' reporting symptoms of waking with shortness of breath, asthma attacks or using asthma medication in stage 1 was also studied. In ECRHS II, subjects who had participated in the clinical phase of ECRHS I were invited to participate in the follow-up. The clinical phase of ECRHS I and II was performed between 1991-1994 and 1998-2002, respectively. ECRHS III is the second follow-up and was performed from February 2011 to January $2014 .{ }^{19} 20$ The present study is based on data from ECRHS III except for 
Table 2 Association between the number of insomnia symptoms, lung function and respiratory symptoms in adults from ECRHS III (mean \pm SD and \%)

\begin{tabular}{|c|c|c|c|c|c|}
\hline & $\begin{array}{l}\text { No insomnia } \\
\text { symptom } \\
(n=3516)\end{array}$ & $\begin{array}{l}\text { One insomnia } \\
\text { symptom } \\
(n=1387)\end{array}$ & $\begin{array}{l}\text { Two insomnia } \\
\text { symptoms } \\
(n=583)\end{array}$ & $\begin{array}{l}\text { Three insomnia } \\
\text { symptoms } \\
(\mathrm{n}=314)\end{array}$ & $P$ value \\
\hline \multicolumn{6}{|l|}{ Respiratory symptom } \\
\hline Wheeze & 21.3 & 26.9 & 29.3 & 36.3 & $<0.0001$ \\
\hline Nocturnal chest tightness & 11.0 & 17.3 & 21.2 & 29.3 & $<0.0001$ \\
\hline Breathless ness at rest & 5.8 & 7.4 & 10.4 & 18.3 & $<0.0001$ \\
\hline Breathlessness after effort & 19.3 & 26.6 & 28.7 & 36.5 & $<0.0001$ \\
\hline Nocturnal breathlessness & 6.4 & 8.9 & 12.6 & 18.8 & $<0.0001$ \\
\hline Nocturnal cough & 28.1 & 35.0 & 40.2 & 46.8 & $<0.0001$ \\
\hline Morning cough & 9.8 & 12.9 & 17.0 & 18.3 & $<0.0001$ \\
\hline Morning phlegm & 11.8 & 13.6 & 19.4 & 19.4 & $<0.0001$ \\
\hline \multicolumn{6}{|l|}{ Lung function } \\
\hline $\mathrm{FEV}_{1}(\%$ pred) pre & $95.4 \pm 14.6$ & $93.9 \pm 14.8$ & $93.6 \pm 15.2$ & $92.8 \pm 16.3$ & 0.0004 \\
\hline FVC (\% pred) pre & $99.4 \pm 13.3$ & $98.3 \pm 13.7$ & $98.4 \pm 14.3$ & $98.3 \pm 14.5$ & 0.046 \\
\hline $\mathrm{FEV}_{1}^{\prime}$ FVC pre & $0.76 \pm 0.06$ & $0.76 \pm 0.07$ & $0.75 \pm 0.07$ & $0.75 \pm 0.07$ & 0.008 \\
\hline $\mathrm{FEV}_{1}(\%$ pred) post & $97.7 \pm 14.2$ & $96.6 \pm 14.2$ & $96.0 \pm 14.9$ & $96.0 \pm 15.5$ & 0.02 \\
\hline FVC (\% pred) post & $98.6 \pm 13.0$ & $98.1 \pm 12.9$ & $97.9 \pm 13.7$ & $98.0 \pm 14.0$ & 0.49 \\
\hline $\mathrm{FEV}_{1} / \mathrm{FVC}$ post & $0.78 \pm 0.06$ & $0.78 \pm 0.07$ & $0.78 \pm 0.07$ & $0.77 \pm 0.07$ & 0.06 \\
\hline Change in $\mathrm{FEV}_{1}$ pre (\% pred) & $-4.5 \pm 10.1$ & $-5.5 \pm 10.8$ & $-5.8 \pm 10.1$ & $-5.3 \pm 11.6$ & 0.01 \\
\hline Change in FVC pre (\% pred) & $-0.89 \pm 9.2$ & $-1.9 \pm 10.1$ & $-1.8 \pm 9.9$ & $-0.53 \pm 10.4$ & 0.01 \\
\hline
\end{tabular}

Insomnia symptom refers to individuals who have symptoms of either initial, middle or late insomnia $\geq 3 \times /$ week.

ECRHS III, European Community Respiratory Health Survey III; FEV , forced expiratory volume in $1 \mathrm{~s}$; FVC, forced vital capacity.

change in lung function which shows the change from ECRHS I- III (see below).

\section{Questionnaires and measurements}

Subjects answered the core ECRHS questionnaires that included questions on respiratory symptoms and smoking history. The following respiratory symptoms were assessed: wheeze, nocturnal chest tightness or attacks of breathlessness following activity, at rest or at night during and attacks of nocturnal cough the last 12 months as well as usually having to cough in the morning and usually bringing up phlegm in the morning.

Sleep-related symptoms were assessed by using the Basic Nordic Sleep Questionnaire, ${ }^{21}$ where participants were asked about frequency of insomnia symptoms. Answers were on a scale of 1-5: (1) never or very seldom, (2) less than once a week, (3) once to twice a week, (4) three to five times a week and (5) every day or almost every day of the week. Insomnia symptoms were defined using answers to three questions from the BSNQ: 'I have difficulties falling asleep at night' (initial insomnia), 'I wake up often during the night' (middle insomnia) and 'I wake up early in the morning and can't fall back asleep' (late insomnia). Those who reported those symptoms of insomnia $\geq 3$ times a week (scores 4 and 5) were considered to have the appropriate subtype. At ECRHS III, forced expiratory volume in one second $\left(\mathrm{FEV}_{1}\right)$ and forced vital capacity (FVC) were recorded prebronchodilation and postbronchodilation with $200 \mu \mathrm{g}$ salbutamol, using the EasyOne NDD spirometer. All subjects made at least five forced expiratory manoeuvres, and maximal values with up to $150 \mathrm{~mL}$ reproducibility were used for analysis. Predicted values were calculated using data from the Global Lung function Initiative. ${ }^{22}$ In ECRHS I and II, spirometry data were recorded similarly, but no bronchodilation was performed. Change in prebronchodilatory lung function from ECRHS I to III was calculated as change in $\%$ of predicted between the surveys.

Height and weight were measured at the time of the spirometry, and body mass index (BMI) was calculated

\section{Patient and public involvement}

Patients and public were not involved in the designing process of this study. The purpose of this research was introduced to all participating patients, and informed consents were sought from all the participants. All participants completed this survey on the voluntary basis. No patient was asked for advice on interpretation or writing up of results. The results of the research will not be disseminated to the patients.

\section{Statistics}

Data are presented as number and percentage or mean $\pm \mathrm{SD}$, depending on distribution. The random 
Table 3 Association between the isolated insomnia subtypes and lung function and respiratory symptoms ( $m e a n \pm S D$ and \%)

\begin{tabular}{|c|c|c|c|c|c|c|c|}
\hline & $\begin{array}{l}\text { No insomnia } \\
\text { symptom } \\
(n=3516)\end{array}$ & $\begin{array}{l}\text { Isolated initial } \\
\text { insomnia } \\
(n=180)\end{array}$ & $P$ value & $\begin{array}{l}\text { Isolated middle } \\
\text { insomnia } \\
(n=991)\end{array}$ & $P$ value & $\begin{array}{l}\text { Isolated late } \\
\text { insomnia } \\
(n=216)\end{array}$ & $P$ value \\
\hline \multicolumn{8}{|l|}{ Respiratory symptom } \\
\hline Nocturnal chest tightness & 11.0 & 24.6 & $<0.0001$ & 15.9 & $<0.0001$ & 17.4 & 0.005 \\
\hline Breathlessness at rest & 5.8 & 10.7 & 0.008 & 6.7 & 0.31 & 7.4 & 0.34 \\
\hline Nocturnal breathlessness & 6.4 & 10.9 & 0.02 & 7.7 & 0.13 & 12.3 & 0.001 \\
\hline Nocturnal cough & 28.1 & 36.3 & 0.02 & 34.2 & $<0.0001$ & 37.6 & 0.003 \\
\hline Morning cough & 9.8 & 14.4 & 0.046 & 12.0 & 0.04 & 15.4 & 0.008 \\
\hline Morning phlegm & 11.8 & 16.3 & 0.07 & 12.6 & 0.52 & 16.4 & 0.048 \\
\hline \multicolumn{8}{|l|}{ Lung function } \\
\hline $\mathrm{FEV}_{1}(\%$ pred $)$ post & $97.7 \pm 14.2$ & $94.4 \pm 14.5$ & 0.005 & $97.1 \pm 14.1$ & 0.33 & $96.4 \pm 14.5$ & 0.24 \\
\hline FVC (\% pred) post & $98.6 \pm 13.0$ & $96.6 \pm 12.4$ & 0.06 & $98.3 \pm 13.0$ & 0.55 & $98.3 \pm 13.1$ & 0.72 \\
\hline $\mathrm{FEV}_{1} / \mathrm{FVC}$ post & $0.78 \pm 0.06$ & $0.78 \pm 0.07$ & 0.34 & $0.78 \pm 0.07$ & 0.56 & $0.78 \pm 0.06$ & 0.19 \\
\hline Change in $\mathrm{FEV}_{1}$ pre (\% pred) & $-4.5 \pm 10.1$ & $-5.7 \pm 9.9$ & 0.18 & $-5.3 \pm 10.9$ & 0.052 & $-6.2 \pm 11.0$ & 0.04 \\
\hline Change in FVC pre (\% pred) & $-0.89 \pm 9.2$ & $-1.7 \pm 11.7$ & 0.29 & $-1.8 \pm 10.0$ & 0.02 & $-2.5 \pm 9.4$ & 0.03 \\
\hline
\end{tabular}

$\mathrm{FEV}_{1}$, forced expiratory volume in $1 \mathrm{~s}$; FVC, forced vital capacity.

sample from ECRHS III was used when comparing prevalence between participants from different countries. The whole sample (random and symptomatic) was used for all other analyses as our aim in these analyses was to examine associations with respiratory symptoms and lung function and not to estimate incidence rates or prevalence in a representative population. For bivariate analysis, the $\chi^{2}$ test, t-test and one-way analysis of variance were used for nominal and continuous variables. Logistic regression was used for multivariable analyses to estimate the association between insomnia and respiratory symptoms after adjusting for potential confounders such as sex, age, BMI and smoking status. In a previous study in the same population, we found associations between nocturnal gastrooesophageal reflux and respiratory symptoms, while habitual snoring was independently associated with both symptoms and lung function. ${ }^{23}$ We therefore performed a sensitivity analyses including nocturnal gastrooesophageal reflux and snoring in the multivariable analyses. STATA V.15 was used for all statistical analyses.

\section{RESULTS}

\section{Geographical variation}

Data from 23 centres and 11 countries were gathered. Of the participants, 5043 were from the random sample. ${ }^{19}$ The overall prevalence of any insomnia symptom was $39.4 \%$. Middle insomnia (31.3\%) was the most common subtype followed by late insomnia $(15.3 \%)$ and initial insomnia (11.3\%) (figure 1). There was a considerable overlap between the three subtypes of insomnia (figure 1).

The highest prevalence of middle insomnia was found in Iceland and the lowest in Australia, while the prevalence of initial insomnia and late insomnia was highest in Spain and lowest in Denmark. The pattern of the prevalence of different subtypes was consistent across countries with initial insomnia being less common than late insomnia and middle insomnia being the most common subtype (figure 2 ).

\section{Respiratory symptoms and lung function}

After including the symptomatic sample, a total of 5800 subjects were included in the analysis. The characteristics of participants with or without insomnia symptoms are presented in table 1. Subjects reporting insomnia symptoms were more often women, older, more likely to be ex-smokers and had a higher BMI.

The prevalence of most respiratory symptoms increased with the number of insomnia symptoms (table 2). There was also a significant association between lung function and insomnia symptoms for most of the lung function variables.

The association between isolated insomnia subtypes and lung function and respiratory symptoms is presented in table 3. All three subtypes were associated with a higher prevalence of most respiratory symptoms. Isolated initial insomnia was significantly associated with a low prebronchodilator and postbronchodilator $\mathrm{FEV}_{1}$ and a low prebronchodilator FVC (table 3). 
Table 4 Independent association between number of insomnia symptoms and also between the isolated insomnia subtypes and lung function and respiratory symptoms expressed as adjusted beta estimates $(95 \% \mathrm{Cl})$ and adjusted ORs $(95 \% \mathrm{Cl})$

\begin{tabular}{|c|c|c|c|c|c|c|}
\hline & $\begin{array}{l}\text { One insomnia } \\
\text { symptom }\end{array}$ & $\begin{array}{l}\text { Two insomnia } \\
\text { symptoms }\end{array}$ & $\begin{array}{l}\text { Three } \\
\text { insomnia } \\
\text { symptoms }\end{array}$ & $\begin{array}{l}\text { Isolated } \\
\text { initial } \\
\text { insomnia }\end{array}$ & $\begin{array}{l}\text { Isolated } \\
\text { middle } \\
\text { insomnia }\end{array}$ & $\begin{array}{l}\text { Isolated late } \\
\text { insomnia }\end{array}$ \\
\hline Respiratory symptom* & OR $(95 \% \mathrm{Cl})$ & OR $(95 \% \mathrm{Cl})$ & OR $(95 \% \mathrm{Cl})$ & OR $(95 \% \mathrm{Cl})$ & OR $(95 \% \mathrm{Cl})$ & OR $(95 \% \mathrm{Cl})$ \\
\hline Wheeze & $\begin{array}{l}1.37(1.17 \text { to } \\
1.61)\end{array}$ & $\begin{array}{l}1.42(1.13 \text { to } \\
1.79)\end{array}$ & $\begin{array}{l}2.13(1.60 \text { to } \\
2.83)\end{array}$ & $\begin{array}{l}1.66(1.15 \text { to } \\
2.40)\end{array}$ & $\begin{array}{l}1.27(1.05 \text { to } \\
1.53)\end{array}$ & $\begin{array}{l}1.54(1.20 \text { to } \\
2.16)\end{array}$ \\
\hline $\begin{array}{l}\text { Nocturnal chest } \\
\text { tightness }\end{array}$ & $\begin{array}{l}1.68 \text { (1.38 to } \\
2.04)\end{array}$ & $\begin{array}{l}2.11 \text { (1.63 to } \\
2.73)\end{array}$ & $\begin{array}{l}3.27(2.41 \text { to } \\
4.43)\end{array}$ & $\begin{array}{l}2.15 \text { (1.43 to } \\
3.23)\end{array}$ & $\begin{array}{l}1.63(1.30 \text { to } \\
2.05)\end{array}$ & $\begin{array}{l}1.55 \text { (1.03 to } \\
2.33)\end{array}$ \\
\hline Breathlessness at rest & $\begin{array}{l}1.30(0.99 \text { to } \\
1.72)\end{array}$ & $\begin{array}{l}1.91(1.36 \text { to } \\
2.68)\end{array}$ & $\begin{array}{l}3.15(2.18 \text { to } \\
4.55)\end{array}$ & $\begin{array}{l}1.66(0.96 \text { to } \\
2.88)\end{array}$ & $\begin{array}{l}1.23(0.89 \text { to } \\
1.70)\end{array}$ & $\begin{array}{l}1.14 \text { (0.63 to } \\
2.05)\end{array}$ \\
\hline $\begin{array}{l}\text { Breathlessness after } \\
\text { effort }\end{array}$ & $\begin{array}{l}1.47(1.24 \text { to } \\
1.74)\end{array}$ & $\begin{array}{l}1.66(1.31 \text { to } \\
2.10)\end{array}$ & $\begin{array}{l}2.45 \text { (1.84 to } \\
3.26)\end{array}$ & $\begin{array}{l}1.80(1.23 \text { to } \\
2.63)\end{array}$ & $\begin{array}{l}1.39(1.14 \text { to } \\
1.69)\end{array}$ & $\begin{array}{l}1.44 \text { ( } 0.995 \text { to } \\
2.08)\end{array}$ \\
\hline $\begin{array}{l}\text { Nocturnal } \\
\text { breathlessness }\end{array}$ & $\begin{array}{l}1.51(1.17 \text { to } \\
1.95)\end{array}$ & $\begin{array}{l}2.31(1.68 \text { to } \\
3.18)\end{array}$ & $\begin{array}{l}3.33(2.33 \text { to } \\
4.76)\end{array}$ & $\begin{array}{l}1.59(0.91 \text { to } \\
2.78)\end{array}$ & $\begin{array}{l}1.36(1.01 \text { to } \\
1.85)\end{array}$ & $\begin{array}{l}1.87(1.17 \text { to } \\
2.99)\end{array}$ \\
\hline Nocturnal cough & $\begin{array}{l}1.31 \text { ( } 1.13 \text { to } \\
1.52)\end{array}$ & $\begin{array}{l}1.67(1.36 \text { to } \\
2.05)\end{array}$ & $\begin{array}{l}1.92(1.48 \text { to } \\
2.51)\end{array}$ & $\begin{array}{l}1.22(0.85 \text { to } \\
1.73)\end{array}$ & $\begin{array}{l}1.27(1.07 \text { to } \\
1.51)\end{array}$ & $\begin{array}{l}1.53 \text { (1.11 to } \\
2.11)\end{array}$ \\
\hline Morning cough & $\begin{array}{l}1.53(1.24 \text { to } \\
1.89)\end{array}$ & $\begin{array}{l}2.09(1.59 \text { to } \\
2.73)\end{array}$ & $\begin{array}{l}2.12(1.50 \text { to } \\
2.98)\end{array}$ & $\begin{array}{l}1.53(0.96 \text { to } \\
2.44)\end{array}$ & $\begin{array}{l}1.51(1.18 \text { to } \\
1.93)\end{array}$ & $\begin{array}{l}1.66 \text { (1.70 to } \\
2.55)\end{array}$ \\
\hline Morning & $\begin{array}{l}1.17 \text { (0.96 to } \\
1.44)\end{array}$ & $\begin{array}{l}1.89 \text { (1.46 to } \\
2.44)\end{array}$ & $\begin{array}{l}1.73 \text { (1.24 to } \\
2.42)\end{array}$ & $\begin{array}{l}1.10(0.69 \text { to } \\
1.77)\end{array}$ & $\begin{array}{l}1.15(0.91 \text { to } \\
1,46)\end{array}$ & $\begin{array}{l}1.30(0.86 \text { to } \\
1.99)\end{array}$ \\
\hline Lung function* & Beta $(95 \% \mathrm{Cl})$ & Beta $(95 \% \mathrm{Cl})$ & Beta $(95 \% \mathrm{Cl})$ & Beta $(95 \% \mathrm{Cl})$ & Beta $(95 \% \mathrm{Cl})$ & Beta $(95 \% \mathrm{Cl})$ \\
\hline $\mathrm{FEV}_{1}(\%$ pred) pre & $\begin{array}{l}-1.04(-2.02 \\
\text { to }-0.06)\end{array}$ & $\begin{array}{l}-1.02(-2.42 \text { to } \\
0.38)\end{array}$ & $\begin{array}{l}-2.25(-4.08 \text { to } \\
-0.41)\end{array}$ & $\begin{array}{l}-2.87(-5.23 \\
\text { to }-0.51)\end{array}$ & $\begin{array}{l}-0.57(-1.68 \text { to } \\
0.53)\end{array}$ & $\begin{array}{l}-1.38(-3.50 \text { to } \\
0.82)\end{array}$ \\
\hline FVC (\% pred) pre & $\begin{array}{l}-0.68(-1.57 \\
\text { to } 0.22)\end{array}$ & $\begin{array}{l}-0.40(-1.69 \text { to } \\
0.88)\end{array}$ & $\begin{array}{l}-1.30(-2.98 \text { to } \\
0.38)\end{array}$ & $\begin{array}{l}-2.59(-4.74 \\
\text { to }-0.44)\end{array}$ & $\begin{array}{l}-0.24(-1.24 \text { to } \\
0.76)\end{array}$ & $\begin{array}{l}-0.57(-2.53 \text { to } \\
1.39)\end{array}$ \\
\hline $\mathrm{FEV}_{1} / \mathrm{FVC}$ pre & $\begin{array}{l}-0.00(-0.01 \\
\text { to } 0.003)\end{array}$ & $\begin{array}{l}-0.01(-0.01 \text { to } \\
0.000)\end{array}$ & $\begin{array}{l}-0.01(-0.01 \text { to } \\
0.001)\end{array}$ & $\begin{array}{l}0.00(-0.01 \text { to } \\
0.01)\end{array}$ & $\begin{array}{l}-0.00(-0.01 \text { to } \\
0.003)\end{array}$ & $\begin{array}{l}-0.01(-0.02 \text { to } \\
0.001)\end{array}$ \\
\hline $\mathrm{FEV}_{1}(\%$ pred) post & $\begin{array}{l}-0.64(-1.60 \\
\text { to } 0.32)\end{array}$ & $\begin{array}{l}-0.96(-2.35 \text { to } \\
0.43)\end{array}$ & $\begin{array}{l}-1.51(-3.31 \text { to } \\
0.29)\end{array}$ & $\begin{array}{l}-2.45(-4.72 \\
\text { to }-0.18)\end{array}$ & $\begin{array}{l}-0.24(-1.31 \text { to } \\
0.84)\end{array}$ & $\begin{array}{l}-0.62(-2.73 \text { to } \\
1.49)\end{array}$ \\
\hline FVC (\% pred) post & $\begin{array}{l}-0.30(-1.18 \\
\text { to } 0.59)\end{array}$ & $\begin{array}{l}-0.23(-1.51 \text { to } \\
1.5)\end{array}$ & $\begin{array}{l}-0.82(-2.47 \text { to } \\
0.83)\end{array}$ & $\begin{array}{l}-1.69(-3.78 \\
\text { to } 0.41)\end{array}$ & $\begin{array}{l}0.00(-1.00 \text { to } \\
0.99)\end{array}$ & $\begin{array}{l}0.06(-1.88 \text { to } \\
2.01)\end{array}$ \\
\hline $\mathrm{FEV}_{1} /$ FVC post & $\begin{array}{l}-0.00(0.01 \text { to } \\
0.003)\end{array}$ & $\begin{array}{l}-0.00(-0.01 \text { to } \\
0.001)\end{array}$ & $\begin{array}{l}-0.01(-0.01 \text { to } \\
0.002)\end{array}$ & $\begin{array}{l}-0.00(-0.01 \\
\text { to } 0.01)\end{array}$ & $\begin{array}{l}0.00(-0.005 \text { to } \\
0.005)\end{array}$ & $\begin{array}{l}-0.01(-0.01 \text { to } \\
0.004)\end{array}$ \\
\hline $\begin{array}{l}\text { Change in } \mathrm{FEV}_{1} \text { pre }(\% \\
\text { pred) } \dagger\end{array}$ & $\begin{array}{l}-0.21(-0.90 \\
\text { to } 0.47)\end{array}$ & $\begin{array}{l}-0.55(-1.53 \text { to } \\
0.43)\end{array}$ & $\begin{array}{l}0.25(-1.07 \text { to } \\
1.57)\end{array}$ & $\begin{array}{l}-0.07(-1.68 \\
\text { to } 1.54)\end{array}$ & $\begin{array}{l}-0.09(-0.86 \text { to } \\
0.68)\end{array}$ & $\begin{array}{l}-1.12(-2.58 \text { to } \\
0.35)\end{array}$ \\
\hline $\begin{array}{l}\text { Change in FVC pre (\% } \\
\text { pred) } \dagger\end{array}$ & $\begin{array}{l}-0.37(-1.00 \\
\text { to } 0.25)\end{array}$ & $\begin{array}{l}-0.63(-1.53 \text { to } \\
0.27)\end{array}$ & $\begin{array}{l}0.41(-0.79 \text { to } \\
1.62)\end{array}$ & $\begin{array}{l}-0.27(-1.76 \\
\text { to } 1.21)\end{array}$ & $\begin{array}{l}-0.29(-0.99 \text { to } \\
0.40)\end{array}$ & $\begin{array}{l}-0.90(-2.22 \text { to } \\
0.42)\end{array}$ \\
\hline
\end{tabular}

Statistically significant associations are marked as bold. The reference group are subjects without insomnia symptoms.

${ }^{*}$ Adjusted for age, sex, BMI, pack years and centre.

†In addition to above also adjusted for change in BMI between ECRHS I and III.

BMI, body mass index; ECRHS, European Community Respiratory Health Survey; FEV ${ }_{1}$, forced expiratory volume in $1 \mathrm{~s}$; FVC, forced vital capacity.

\section{Multiple variable analyses}

There was a clear independent association between the number of insomnia symptoms and all respiratory symptoms, whereas there was no association to lung function or decline in lung function after adjustment for age, sex, BMI and smoking (table 4). All three subtypes of insomnia were associated with most of the respiratory symptoms. Isolated early insomnia was independently associated with both prebronchodilatory and postbronchodilatory $\mathrm{FEV}_{1}$, whereas no association to $\mathrm{FEV}_{1} / \mathrm{FVC}$ ratio or decline of lung function as measured as prebronchodilator was found for any of the insomnia subtypes. Most associations remained statistically significant also after including nocturnal gastro-oesophageal reflux and habitual snoring in the model (table 5).

\section{DISCUSSION}

In the present study, almost one out of three subjects had symptoms of middle insomnia, $14 \%$ had late insomnia and $11 \%$ initial insomnia. We have reported such high prevalence of middle insomnia (especially related to obstructive sleep apnoea), ${ }^{13}$ while other general population 
Table 5 Independent association between number of insomnia symptoms and also between the isolated insomnia subtypes and lung function and respiratory symptoms expressed as adjusted beta estimates $(95 \% \mathrm{Cl})$ and adjusted ORs $(95 \% \mathrm{Cl})$

\begin{tabular}{|c|c|c|c|c|c|c|}
\hline & $\begin{array}{l}\text { One insomnia } \\
\text { symptom }\end{array}$ & $\begin{array}{l}\text { Two insomnia } \\
\text { symptoms }\end{array}$ & $\begin{array}{l}\text { Three insomnia } \\
\text { symptoms }\end{array}$ & $\begin{array}{l}\text { Isolated initial } \\
\text { insomnia }\end{array}$ & $\begin{array}{l}\text { Isolated middle } \\
\text { insomnia }\end{array}$ & $\begin{array}{l}\text { Isolated late } \\
\text { insomnia }\end{array}$ \\
\hline Respiratory symptom ${ }^{*}$ & OR $(95 \% \mathrm{Cl})$ & OR $(95 \% \mathrm{Cl})$ & OR $(95 \% \mathrm{Cl})$ & OR $(95 \% \mathrm{Cl})$ & OR (95\% Cl) & OR $(95 \% \mathrm{Cl})$ \\
\hline Wheeze & $\begin{array}{l}1.29(1.07 \text { to } \\
1.56)\end{array}$ & $\begin{array}{l}1.22 \text { (0.93 to } \\
1.56)\end{array}$ & $\begin{array}{l}1.83(1.30 \text { to } \\
2.56)\end{array}$ & 1.26 (0.80 to 2.00$)$ & $\begin{array}{l}1.24 \text { (0.997 to } \\
1.54)\end{array}$ & $\begin{array}{l}1.49(0.97 \text { to } \\
2.24)\end{array}$ \\
\hline $\begin{array}{l}\text { Nocturnal chest } \\
\text { tightness }\end{array}$ & $\begin{array}{l}1.54 \text { (1.21 to } \\
1.95)\end{array}$ & $\begin{array}{l}2.07 \text { (1.52 to } \\
2.83)\end{array}$ & $\begin{array}{l}2.81 \text { (1.92 to } \\
4.10)\end{array}$ & $\begin{array}{l}1.94(1.16 \text { to } \\
3.22)\end{array}$ & $\begin{array}{l}1.53(1.16 \text { to } \\
2.01)\end{array}$ & $\begin{array}{l}1.39(0.82 \text { to } \\
2.35)\end{array}$ \\
\hline Breathlessness at rest & $\begin{array}{l}1.32 \text { (0.93 to } \\
1.87)\end{array}$ & $\begin{array}{l}2.20(1.46 \text { to } \\
3.32)\end{array}$ & $\begin{array}{l}3.73(2.37 \text { to } \\
5.87)\end{array}$ & 1.55 (0.74 to 3.24$)$ & $\begin{array}{l}1.19(0.79 \text { to } \\
1.79)\end{array}$ & $\begin{array}{l}1.46(0.72 \text { to } \\
2.94)\end{array}$ \\
\hline $\begin{array}{l}\text { Breathles } \\
\text { effort }\end{array}$ & $\begin{array}{l}1.50 \text { (1.23 to } \\
1.83)\end{array}$ & $\begin{array}{l}1.62(1.23 \text { to } \\
2.13)\end{array}$ & $\begin{array}{l}2.19 \text { (1.55 to } \\
3.09)\end{array}$ & $\begin{array}{l}1.99(1.28 \text { to } \\
3.10)\end{array}$ & $\begin{array}{l}1.43(1.15 \text { to } \\
1.79)\end{array}$ & $\begin{array}{l}1.37 \text { (0.85 to } \\
2.11)\end{array}$ \\
\hline $\begin{array}{l}\text { Nocturnal } \\
\text { breathlessness }\end{array}$ & $\begin{array}{l}1.33 \text { (0.96 to } \\
1.84)\end{array}$ & $\begin{array}{l}2.01 \text { (1.34 to } \\
3.02)\end{array}$ & $\begin{array}{l}3.29(2.1 \\
5.16)\end{array}$ & 0.99 (0.43 to 2.27$)$ & $\begin{array}{l}1.22(0.83 \text { to } \\
1.79)\end{array}$ & $\begin{array}{l}2.03(1.11 \text { to } \\
3.70)\end{array}$ \\
\hline Nocturnal & $\begin{array}{l}1.23(1.04 \text { to } \\
1.45)\end{array}$ & $\begin{array}{l}1.46(1.16 \text { to } \\
1.84)\end{array}$ & $\begin{array}{l}1.76(1.29 \text { to } \\
2.39)\end{array}$ & 1.15 & $\begin{array}{l}1.21 \text { (1.001 to } \\
1.46)\end{array}$ & $\begin{array}{l}1.45(0.63 \text { to } \\
2.38)\end{array}$ \\
\hline Morn & $\begin{array}{l}1.51(1.18 \text { to } \\
1.92)\end{array}$ & $\begin{array}{l}1.91 \text { (1.39 to } \\
2.61)\end{array}$ & $\begin{array}{l}2.06 \text { (1.38 to } \\
3.07)\end{array}$ & 1.40 & $\begin{array}{l}1.54(1.17 \text { to } \\
2.04)\end{array}$ & $\begin{array}{l}1.59(0.95 \text { to } \\
2.68)\end{array}$ \\
\hline Morning phlegm & $\begin{array}{l}1.15 \text { (0.91 to } \\
1.45)\end{array}$ & $\begin{array}{l}1.68(1.25 \text { to } \\
2.26)\end{array}$ & $\begin{array}{l}1.49(0.99 \text { to } \\
2.24)\end{array}$ & 1.20 (0.70 to 2.06$)$ & $\begin{array}{l}1.17(0.90 \text { to } \\
1.53)\end{array}$ & $\begin{array}{l}1.06(0.62 \text { to } \\
1.80)\end{array}$ \\
\hline Lung function* & Beta $(95 \% \mathrm{Cl})$ & Beta $(95 \% \mathrm{Cl})$ & Beta $(95 \% \mathrm{Cl})$ & Beta $(95 \% \mathrm{Cl})$ & Beta $(95 \% \mathrm{Cl})$ & Beta $(95 \% \mathrm{Cl})$ \\
\hline $\mathrm{FEV}_{1}(\%$ pred) pre & $\begin{array}{l}-0.87(-1.92 \text { to } \\
0.19)\end{array}$ & $\begin{array}{l}-0.86(-2.37 \text { to } \\
0.64)\end{array}$ & $\begin{array}{l}-2.04(-4.08 \text { to } \\
-0.01)\end{array}$ & $\begin{array}{l}-3.33(-5.94 \text { to } \\
-0.72)\end{array}$ & $\begin{array}{l}-0.57(-1.74 \text { to } \\
0.61)\end{array}$ & $\begin{array}{l}0.24(-2.14 \text { to } \\
2.62)\end{array}$ \\
\hline FVC (\% pred) pre & $\begin{array}{l}-0.42(-1.41 \text { to } \\
0.57)\end{array}$ & $\begin{array}{l}-0.25(-1.67 \text { to } \\
1.16)\end{array}$ & $\begin{array}{l}-0.85(-2.76 \text { to } \\
1.07)\end{array}$ & $\begin{array}{l}-2.48(-4.91 \text { to } \\
-0.04)\end{array}$ & $\begin{array}{l}-0.20(-1.29 \text { to } \\
0.90)\end{array}$ & $\begin{array}{l}0.88(-1.35 \text { to } \\
3.11)\end{array}$ \\
\hline $\mathrm{FEV}_{1} / \mathrm{FVC}$ pre & $\begin{array}{l}-0.00(-0.01 \text { to } \\
0.002)\end{array}$ & $\begin{array}{l}-0.01(-0.01 \text { to } \\
0.001)\end{array}$ & $\begin{array}{l}-0.01(-0.02 \text { to } \\
-0.001)\end{array}$ & $\begin{array}{l}0.00(-0.01 \text { to } \\
0.01)\end{array}$ & $\begin{array}{l}-0.00(-0.01 \text { to } \\
0.002)\end{array}$ & $\begin{array}{l}-0.01(-0.02 \text { to } \\
0.004)\end{array}$ \\
\hline $\mathrm{FEV}_{1}(\%$ pred) post & $\begin{array}{l}-0.66(-1.70 \text { to } \\
0.38)\end{array}$ & $\begin{array}{l}-0.82(-2.33 \text { to } \\
0.69)\end{array}$ & $\begin{array}{l}-1.73(-3.75 \text { to } \\
0.28)\end{array}$ & $\begin{array}{l}-2.77(-5.29 \text { to } \\
-0.25)\end{array}$ & $\begin{array}{l}-0.37(-1.52 \text { to } \\
0.79)\end{array}$ & $\begin{array}{l}0.37(-1.97 \text { to } \\
2.72)\end{array}$ \\
\hline FVC (\% pred) post & $\begin{array}{l}-0.27(-1.24 \text { to } \\
0.70)\end{array}$ & $\begin{array}{l}-0.10(-1.51 \text { to } \\
1.32)\end{array}$ & $\begin{array}{l}-0.41(-2.28 \text { to } \\
1.47)\end{array}$ & $\begin{array}{l}-1.47(-3.84 \text { to } \\
0.90)\end{array}$ & $\begin{array}{l}-0.13(-1.21 \text { to } \\
0.96)\end{array}$ & $\begin{array}{l}0.84(-1.36 \text { to } \\
3.03)\end{array}$ \\
\hline $\mathrm{FEV}_{1} / \mathrm{FVC}$ post & $\begin{array}{l}-0.00 \text { (0.01 to } \\
0.003)\end{array}$ & $\begin{array}{l}-0.01(-0.01 \text { to } \\
0.001)\end{array}$ & $\begin{array}{l}-0.01(-0.02 \text { to } \\
-0.001)\end{array}$ & $\begin{array}{l}-0.01(-0.02 \text { to } \\
0.005)\end{array}$ & $\begin{array}{l}0.00(-0.005 \text { to } \\
0.005)\end{array}$ & $\begin{array}{l}-0.01(-0.02 \text { to } \\
0.01)\end{array}$ \\
\hline $\begin{array}{l}\text { Change in } \mathrm{FEV}_{1} \text { pre } \\
\text { (\% pred) } \dagger\end{array}$ & $\begin{array}{l}-0.12(-0.90 \text { to } \\
0.47)\end{array}$ & $\begin{array}{l}-0.64(-1.68 \text { to } \\
0.40)\end{array}$ & $\begin{array}{l}1.09(-0.38 \text { to } \\
0.40)\end{array}$ & $\begin{array}{l}0.29(-1.49 \text { to } \\
2.07)\end{array}$ & $\begin{array}{l}-0.03(-0.84 \text { to } \\
0.79)\end{array}$ & $\begin{array}{l}-1.05(-2.65 \text { to } \\
0.56)\end{array}$ \\
\hline $\begin{array}{l}\text { Change in FVC pre (\% } \\
\text { pred) } \dagger\end{array}$ & $\begin{array}{l}-0.30(-0.98 \text { to } \\
0.38)\end{array}$ & $\begin{array}{l}-0.84(-1.81 \text { to } \\
0.13)\end{array}$ & $\begin{array}{l}0.95(-0.40 \text { to } \\
2.30)\end{array}$ & $\begin{array}{l}-0.05(-1.72 \text { to } \\
1.62)\end{array}$ & $\begin{array}{l}-0.38(-1.13 \text { to } \\
0.37)\end{array}$ & $\begin{array}{l}-0.12(-1.60 \text { to } \\
1.37)\end{array}$ \\
\hline
\end{tabular}

Statistically significant associations are marked as bold. The reference group are subjects without insomnia symptoms.

${ }^{*}$ Adjusted for age, sex, BMI, pack years, nocturnal gastro-oesophageal reflux, habitual snoring and centre.

†In addition to above also adjusted for change in BMI between ECRHS I and III.

BMI, body mass index; ECRHS, European Community Respiratory Health Survey; FEV ${ }_{1}$, forced expiratory volume in 1 s; FVC, forced vital capacity.

based studies have not found middle insomnia to be the most prevalent subtype. ${ }^{24}$ All subtypes of insomnia were related to an increased prevalence of respiratory symptoms, and having initial insomnia was also related to lower lung function. The prevalence of middle insomnia was highest in Iceland, whereas the prevalence of early and late insomnia was highest in Spain.

Others studies have not compared the prevalence of insomnia subtypes between different countries in Europe and Australia, but they have however also reported geographical differences in sleep disorders. ${ }^{6-10}$ In our previous analyses of these data as used in this one, ${ }^{19}$ we found considerable differences in sleep duration between centres, and the highest percentage of short sleepers were in the Spanish centres. In the current study, we also found a trend in Spain where both initial and late insomnia subtypes are most common there. These differences might be explained by cultural differences, working hours, unemployment and other social or economic factors, but we lack comparative data to study that further.

In the present study, we found an independent association between insomnia symptoms and respiratory symptoms. An association between insomnia and respiratory disorders such as asthma and COPD have been reported in previous studies, ${ }^{11} 1425$ but to our knowledge, no data exist on the association between different insomnia subtypes and 
respiratory symptoms. A possible explanation for an association between poor respiratory health and insomnia could be some abnormal ventilatory mechanics and/or nocturnal respiratory symptoms such as cough and/or breathing difficulties. ${ }^{26}$ Within the rich ECRHS data set, we hope to be able to enlighten the 'whole picture' further by also evaluating the possible role of physical activity, worse general health and impaired quality of life among subjects with both insomnia and respiratory symptoms.

In accordance with previous studies, participants with insomnia symptoms in the present study had a higher BMI than subjects without insomnia. ${ }^{27} 28$ Obesity is also related to other disorders that influence sleep such as nocturnal gastroesophageal reflux (nGER) and obstructive sleep apnoea. The association between respiratory and insomnia symptoms remained significant also after adjusting for nocturnal gastro-oesophageal reflux and snoring. It further strengthens an independent association between insomnia and respiratory symptoms.

In the present study, we found that having isolated early insomnia was associated with lower $\mathrm{FEV}_{1}$. In a study by Budhiraja et al, ${ }^{17} \mathrm{FEV}_{1}$ was the same among participants with insomnia compared with those without insomnia. Different insomnia subtypes were, however, not explored in their study. We did not find any significant association between insomnia symptoms and airflow obstruction $\left(\mathrm{FEV}_{1} / \mathrm{FVC}\right)$ or decline in lung function, but it is important to note that most subject in our sample had $\mathrm{FEV}_{1}$ within the normal range. These results are in line with the study of Budhiraja $\mathrm{et} \mathrm{al,}{ }^{17}$ although others have found an association of COPD-related variables with insomnia severity. ${ }^{29}$ Due to these conflicting results and a lack of data regarding this, further studies are needed on this topic. There are several limitations of this study that need to be considered. Our results are from a crosssectional study, and deeper understanding of the direction of the association of underlying causal pathways can only be obtained from longitudinal or intervention studies. The questions used to assess insomnia can only provide information on insomnia symptoms, but we do not have enough information to make an insomnia diagnosis. Another limitation is that we have information about respiratory symptoms, but the occurrence of respiratory illness was not confirmed. The data on geographical variation were only obtained from a limited number of subjects from each country. The strengths of this study include the population-based nature of this large sample collected in the same manner at many centres in 11 different countries and the use of standardised and validated procedures and instruments.

Considering the prevalence and negative health consequences of both insomnia and respiratory disorders in general, these results have important clinical and public health implications. Having in mind that there is a $2-3$ fold increase of reported insomnia among those with respiratory symptoms, both insomnia and respiratory symptoms should be kept in mind when either one is presented clinically. Prospective longitudinal studies need to be designed to ascertain the causality of the association between insomnia and respiratory symptoms. The traditional view is that poorly controlled respiratory symptoms cause insomnia, ${ }^{30}$ but the challenging question is whether both are contributing to a viscous circle and insomnia making respiratory symptoms like in asthma more pronounced. Awakening from sleep is associated with increased sympathetic activity and that can in turn cause airway inflammation, wheezing and coughing. ${ }^{30}$ Studies assessing the possible effect of interventions for comorbid insomnia among patients with respiratory symptoms (medications and/or cognitive behavioural therapy) might theoretically improve the clinical conditions among such patients.

To summarise, our results show a large geographical variation between different subtypes of insomnia. Symptoms of insomnia are related to respiratory symptoms and isolated initial insomnia is associated with lower $\mathrm{FEV}_{1}$. Whether improvement in insomnia affect respiratory health or whether treatment of respiratory symptoms affect insomnia is still to be investigated.

\section{Author affiliations}

${ }^{1}$ Haskolinn i Reykjavik, Reykjavik, Iceland

${ }^{2}$ Faculty of Medicine, School of Health Sciences, University of Iceland, Reykjavik, Iceland

${ }^{3}$ Respiratory Medicine and Allegology, Uppsala University, Uppsala, Sweden ${ }^{4}$ Department of Respiratory Medicine and Sleep, Landspitali - The National University Hospital of Iceland, Reykjavik, Iceland

${ }^{5}$ Johns Hopkins Bloomberg School of Public Health, Baltimore, Maryland, USA ${ }^{6}$ Department of Surgery, Surgical and Perioperative Sciences, Umeå, Sweden ${ }^{7}$ Department of Respiratory Epidemiology and Public Health, Imperial College, London, UK

${ }^{8}$ Pneumology Department, University Hospital of Montpellier, Montpellier, France

${ }^{9}$ University of Melbourne, Melbourne, Victoria, Australia

${ }^{10}$ Centre for Research in Environmental Epidemiology (CREAL), Instituto de Salud Global Barcelona, Barcelona, Catalunya, Spain

${ }^{11}$ Pulmonology Department, Hospital Galdakao-Usansolo, Galdacano, País Vasco, Spain

${ }^{12}$ Institute and Outpatient Clinic for Occupational, Social and Environmental Medicine, Clinical Center, Ludwig Maximilians University, Comprehensive Pneumology Centre Munich, German Centre for Lung Research, Muenchen, Germany

${ }^{13}$ Department of Occupational and Environmental Medicine, University of Gothenburg, Gothenburg, Sweden

${ }^{14}$ Tartu University, Tartu, Estonia

${ }^{15}$ Department of Respiratory Medicine, Uppsala University, Uppsala, Sweden

Acknowledgements The authors would like to thank all members of the research team at each centre for the patient advisers and for the assistance in data collection.

Contributors EB is the correspondence author and she drafted the paper, participated in manuscript preparation and was responsible for communication with authors and reviewing the paper in all its stages; TG and CJ participated in designing the study and in manuscript preparation; CJ performed the statistical analysis; they also reviewed the paper on several stages. EL, BB, VGL, KF, DJ, PD, $\mathrm{JLP}, \mathrm{JGA}, \mathrm{SDA}, \mathrm{JH}, \mathrm{KT}$ and RJ participated in data collection and reviewing the paper.

Funding Financial support for ECRHS III: Australia: National Health \& Medical Research Council. Belgium: Antwerp South, Antwerp City: Research Foundation Flanders (FW0), grant code G.0.410.08.N.10 (both sites). Estonia: TartuSF0180060s09 from the Estonian Ministry of Education. France: (all) Ministère de la Santé. Programme Hospitalier de Recherche Clinique (PHRC) national 2010. Bordeaux: INSERM U897 Université Bordeaux segalen; Grenoble: Comite 
Scientifique AGIRadom 2011; Paris: Agence Nationale de la Santé, Région lle de France, domaine d'intérêt majeur (DIM). Germany: Erfurt: German Research Foundation HE 3294/10-1; Hamburg: German Research Foundation MA 711/6-1, N0 262/7-1. Iceland: Reykjavik: The Landspitali University Hospital Research Fund, University of Iceland Research Fund, ResMed Foundation, California, USA, Orkuveita Reykjavikur (Geothermal plant), Vegagerðin (The Icelandic Road Administration (ICERA). The Icelandic Research found - grant no 173 701-052. Italy: all Italian centres were funded by the Italian Ministry of Health, Chiesi Farmaceutici SpA, in addition Verona was funded by Cariverona foundation, Education Ministry (MIUR). Norway: Norwegian Research council grant no 214123, Western Norway Regional Health Authorities grant no 911631, Bergen Medical Research Foundation. Spain: Fondo de Investigación Sanitaria (PS09/02457, PS09/00716 09/01511) PS09/02185 PS09/03190), Servicio Andaluz de Salud, Sociedad Española de Neumología y Cirurgía Torácica (SEPAR 1001/2010). Sweden: all centres were funded by The Swedish Heart and Lung Foundation, The Swedish Asthma and Allergy Association, The Swedish Association against Lung and Heart Disease. Fondo de Investigación Sanitaria (PS09/02457); Barcelona: Fondo de Investigación Sanitaria (FIS PS09/00716); Galdakao: Fondo de Investigación Sanitaria (FIS 09/01511); Huelva: Fondo de Investigación Sanitaria (FIS PS09/02185); and Servicio Andaluz de Salud Oviedo: Fondo de Investigación Sanitaria (FIS PS09/03190). Sweden: all centres were funded by The Swedish Heart and Lung Foundation, The Swedish Asthma and Allergy Association, The Swedish Association against Lung and Heart Disease. Swedish Research Council for health, working life and welfare (FORTE); Göteborg also received further funding from the Swedish Council for Working life and Social Research. Umea also received funding from Vasterbotten Country Council ALF grant. Switzerland: The Swiss National Science Foundation (grants no 33CSC0-134276/1, 33CSC0-108796, 3247B0-104283, 3247B0-104288, 3247B0-104284, 3247-065896, 3100-059302, 3200-052720, 3200-042532 and 4026-028099), The Federal Office for Forest, Environment and Landscape, The Federal Office of Public Health, The Federal Office of Roads and Transport, the Canton's Government of Aargan, Basel-Stadt, Basel-Land, Geneva, Luzern, Ticino, Valais and Zürich, the Swiss Lung League, The Canton's Lung League of Basel Stadt/ Basel, Landschaft, Geneva, Ticino, Valais and Zurich, SUVA, Freiwillige Akademische Gesellschaft, UBS Wealth Foundation, Talecris Biotherapeutics GmbH, Abbott Diagnostics, European Commission 018996 (GABRIEL), Wellcome Trust WT 084703MA, UK: Medical Research Council (Grant Number 92091). Support also provided by the National Institute for Health Research through the Primary Care Research Network.

Competing interests None declared.

Patient consent for publication Not required.

Ethics approval Ethical approval for the study from local research ethics committees and written consent from participants were obtained. See online supplementary appendix 1.

Provenance and peer review Not commissioned; externally peer reviewed.

Data availability statement Data are available on reasonable request. The data that support the findings of this study are available on request from the corresponding author.

Open access This is an open access article distributed in accordance with the Creative Commons Attribution Non Commercial (CC BY-NC 4.0) license, which permits others to distribute, remix, adapt, build upon this work non-commercially, and license their derivative works on different terms, provided the original work is properly cited, appropriate credit is given, any changes made indicated, and the use is non-commercial. See: http://creativecommons.org/licenses/by-nc/4.0/.

ORCID iDs

Erla Bjornsdottir http://orcid.org/0000-0002-6585-5777

Christer Janson http://orcid.org/0000-0001-5093-6980

\section{REFERENCES}

1 Consensus Conference Panel, Watson NF, Badr MS, et al. Recommended amount of sleep for a healthy adult: a joint consensus statement of the American Academy of sleep medicine and sleep research Society. J Clin Sleep Med 2015;11:591-2.

2 Gottlieb DJ, Redline S, Nieto FJ, et al. Association of usual sleep duration with hypertension: the sleep heart health study. Sleep 2006;29:1009-14.

3 Sivertsen B, Lallukka T, Salo P, et al. Insomnia as a risk factor for ill health: results from the large population-based prospective HUNT study in Norway. J Sleep Res 2014;23:124-32.
4 Lindberg EVA, Carter NED, Gislason T, et al. Role of snoring and daytime sleepiness in occupational accidents. Am J Respir Crit Care Med 2001;164:2031-5.

5 Benca RM. Diagnosis and treatment of chronic insomnia: a review. Psychiatric Services 2005;56:332-43.

6 Léger D, Poursain B, Neubauer D, et al. An international survey of sleeping problems in the general population. Curr Med Res Opin 2008;24:307-17.

7 Janson C, Gislason T, De Backer W, et al. Prevalence of sleep disturbances among young adults in three European countries. Sleep 1995;18:589-97.

8 Chevalier H, Los F, Boichut D, et al. Evaluation of severe insomnia in the general population: results of a European multinational survey. $J$ Psychopharmacol 1999;13:21S-4.

9 Dregan A, Armstrong D. Cross-country variation in sleep disturbance among working and older age groups: an analysis based on the European social survey. Int Psychogeriatr 2011;23:1413-20.

10 van de Straat V, Bracke P. How well does Europe sleep? A crossnational study of sleep problems in European older adults. Int $J$ Public Health 2015;60:643-50.

11 Dodge R, Cline MG, Quan SF. The natural history of insomnia and its relationship to respiratory symptoms. Arch Intern Med 1995:155:1797-800.

12 Klink ME, Dodge R, Quan SF. The relation of sleep complaints to respiratory symptoms in a general population. Chest 1994:105:151-4.

13 Björnsdóttir E, Janson C, Gíslason T, et al. Insomnia in untreated sleep apnea patients compared to controls. J Sleep Res 2012;21:131-8.

14 Janson C, Norbäck D, Omenaas E, et al. Insomnia is more common among subjects living in dAMP buildings. Occup Environ Med 2005;62:113-8.

15 Janson C, De Backer W, Gislason T, et al. Increased prevalence of sleep disturbances and daytime sleepiness in subjects with bronchial asthma: a population study of young adults in three European countries. Eur Respir J 1996:9:2132-8.

16 Sundbom F, Lindberg E, Bjerg A, et al. Asthma symptoms and nasal congestion as independent risk factors for insomnia in a general population: results from the $\mathrm{GA}^{(2)}$ LEN survey. Allergy 2013;68:213-9.

17 Budhiraja R, Siddiqi TA, Quan SF. Sleep disorders in chronic obstructive pulmonary disease: etiology, impact, and management. $J$ Clin Sleep Med 2015;11:259-70.

18 Burney PGJ, Luczynska C, Chinn S, et al. The European community respiratory health survey. Eur Respir J 1994;7:954-60.

19 Björnsdóttir E, Janson C, Lindberg E, et al. Respiratory symptoms are more common among short sleepers independent of obesity. BMJ Open Respir Res 2017;4:e000206.

20 Fuertes E, Carsin A-E, Antó JM, et al. Leisure-Time vigorous physical activity is associated with better lung function: the prospective ECRHS study. Thorax 2018;73:376-84.

21 Partinen M, Gislason T. Basic Nordic sleep questionnaire (BNSQ): a quantitated measure of subjective sleep complaints. J Sleep Res 1995;4:150-5.

22 Quanjer PH, Hall GL, Stanojevic S, et al. Age- and height-based prediction bias in spirometry reference equations. Eur Respir $J$ 2012;40:190-7

23 Emilsson Össur Ingi, Hägg SA, Lindberg E, et al. Snoring and nocturnal reflux: association with lung function decline and respiratory symptoms. ERJ Open Res 2019;5:00010-2019.

24 Morin CM, LeBlanc M, Daley M, et al. Epidemiology of insomnia: prevalence, self-help treatments, consultations, and determinants of help-seeking behaviors. Sleep Med 2006;7:123-30.

25 Budhiraja R, Parthasarathy S, Budhiraja P, et al. Insomnia in patients with COPD. Sleep 2012;35:369-75.

26 Sundbom F, Malinovschi A, Lindberg E, et al. Effects of poor asthma control, insomnia, anxiety and depression on quality of life in young asthmatics. J Asthma 2016;53:398-403.

27 Palm A, Janson C, Lindberg E. The impact of obesity and weight gain on development of sleep problems in a population-based sample. Sleep Med 2015;16:593-7.

28 Cai G-H, Janson C, Theorell-Haglöw J, et al. Both weight at age 20 and weight gain have an impact on sleep disturbances later in life: results of the EpiHealth study. Sleep 2018;41. doi:10.1093/sleep/ zsx176. [Epub ahead of print: 01 Jan 2018].

29 Kapella M, Vispute S, Steffen A, et al. B107 optimizing patient centered approaches in pulmonary. Am J Respir Crit Care Med 2017.

30 Brumpton B, Mai X-M, Langhammer A, et al. Prospective study of insomnia and incident asthma in adults: the HUNT study. Eur Respir J 2017;49:1601327. 